\title{
ANP impairs the dose-dependent stimulatory effect of ANG II or AVP on $\mathbf{H}^{+}$-ATPase subcellular vesicle trafficking*
}

\author{
M. Oliveira-Souza, P. Morethson, G. Malnic, M. Mello-Aires ${ }^{\#}$
}

Department of Physiology and Biophysics, Instituto de Ciências Biomédicas, University of São Paulo, São Paulo, Brazil Email: ${ }^{\#}$ maires@,icb.usp.br

Received 27 May 2013; revised 22 June 2013; accepted 5 July 2013

Copyright (C) 2013 M. Oliveira-Souza et al. This is an open access article distributed under the Creative Commons Attribution License, which permits unrestricted use, distribution, and reproduction in any medium, provided the original work is properly cited.

\begin{abstract}
The effect of angiotensin II (ANG II) or arginine vasopressin (AVP) alone or plus atrial natriuretic peptide (ANP) on $\mathrm{H}^{+}$-ATPase subcellular vesicle trafficking was investigated in MDCK cells following intracellular pH (pHi) acidification by exposure to 20 $\mathrm{mM} \mathrm{NH}_{4} \mathrm{Cl}$ for $2 \mathrm{~min}$ in a $\mathrm{Na}^{+}$-free solution containing Schering 28080, conditions under which $\mathrm{H}^{+}$-ATPase is the only cell mechanism for pHi recovery. Using the acridine orange fluorescent probe $(5 \mu \mathrm{M})$ and confocal microscopy, the vesicle movement was quantified by determining, for each experimental group, the mean slope of the line indicating the changes in apical/basolateral fluorescence density ratio over time during the first $5.30 \mathrm{~min}$ of the pHi recovery period. Under the control conditions, the mean slope was $0.079 \pm 0.0033 \mathrm{~min}^{-1}$ (14) and it increased significantly with ANG II $\left[10^{-12}\right.$ and $10^{-7} \mathrm{M}$, respectively to $0.322 \pm 0.038 \mathrm{~min}^{-1}(13)$ and $0.578 \pm 0.061 \mathrm{~min}^{-1}(12)$ or AVP $\left[10^{-12}\right.$ and $10^{-6} \mathrm{M}$, respectively to $0.301 \pm$ $0.018 \mathrm{~min}^{-1}(12)$ and $0.687 \pm 0.049 \mathrm{~min}^{-1}$ (11)]. However, in presence of ANP $\left(10^{-6} \mathrm{M}\right.$, decreases cytosolic free calcium), dimethyl-BAPTA/AM $\left(5 \times 10^{-5} \mathrm{M}\right.$, chelates intracellular calcium) or colchicine $\left(10^{-5} \mathrm{M}, 2-\mathrm{h}\right.$ preincubation; inhibits microtubule-dependent vesicular trafficking) alone or plus ANG II or AVP the

*Disclosure: No conflicts of interest, financial or otherwise, are declared by the authors.

Author contributions: M. Oliveira-Souza, G. Malnic and M. MelloAires conception and design of research; M. Oliveira-Souza, P. Morethson and G. Malnic performed experiments; M. Oliveira-Souza, P. Morethson, G. Malnic and M. Mello-Aires analyzed data; M. OliveiraSouza, G. Malnic and M. Mello-Aires interpreted results of experiments; M. Oliveira-Souza, P. Morethson and M. Mello-Aires prepared figures; M. Oliveira-Souza, G. Malnic and M. Mello-Aires drafted manuscript; M. Oliveira-Souza, G. Malnic and M. Mello-Aires edited and revised manuscript; M. Oliveira-Souza, G. Malnic and M. MelloAires approved final version of manuscript.

\#Corresponding author.
\end{abstract}

mean slopes were similar to the control values, indicating that such agents blocked the stimulatory effect of ANG II or AVP on vesicle trafficking. The results suggest that the pathway responsible for the increase in cytosolic free calcium and the microtu-bule-dependent vesicular trafficking are involved in this hormonal stimulating effect. Whether cytosolic free calcium reduction represents an important direct mechanism for ANP impairs the dose-dependent stimulatory effect of ANG II or AVP on $\mathrm{H}^{+}$-ATPase subcellular vesicle trafficking, or is a side effect of other signaling pathways which will require additional studies.

Keywords: $\mathrm{H}^{+}$-ATPase Vesicle Trafficking; ANP; ANG II; AVP

\section{INTRODUCTION}

The effect of angiotensin II (ANG II) on $\mathrm{H}^{+}$-ATPase activity is controversial. In proximal [1] and distal [2] rat kidney tubules and in intercalated cells of connecting tubule [3], cortical [3,4] and medullary [5] collecting duct ANG II $\left(10^{-12}-10^{-9} \mathrm{M}\right)$ stimulates $\mathrm{H}^{+}$-ATPase. However, in the rat cortical [6] and outer medullary [7] collecting duct, ANG II $\left(10^{-10}-10^{-5} \mathrm{M}\right)$ causes a dosedependent decrease in $\mathrm{H}^{+}$-ATPase activity. In addition, our studies in MDCK cells, a permanent cell line originated from the renal collecting duct, indicate that after intracellular $\mathrm{pH}(\mathrm{pHi})$ acidification using an $\mathrm{NH}_{4} \mathrm{Cl}$ pulse, ANG II $\left(10^{-12}, 10^{-9}\right.$ or $\left.10^{-7} \mathrm{M}\right)$ stimulates $\mathrm{H}^{+}$-ATPase in a dose-dependent manner by increasing the cytosolic free calcium $\left(\left[\mathrm{Ca}^{2+}\right] \mathrm{i}\right)$. In agreement with these results, atrial natriuretic peptide (ANP) or dimethyl-BAPTA/AM (BAPTA, chelates intracellular calcium) alone decreases the $\left[\mathrm{Ca}^{2+}\right]$ i levels but does not affect the $\mathrm{H}^{+}$-ATPase activity; however, these compounds interfere with the pathway 
responsible for the increase in $\left[\mathrm{Ca}^{2+}\right] \mathrm{i}$, blocking the stimulatory effect of ANG II on $\mathrm{H}^{+}$-ATPase [8].

The effect of arginine vasopressin (AVP) on $\mathrm{H}^{+}$-ATPase activity is unclear. In an in vivo microperfusion study, we demonstrated that in the late distal tubule of rat kidney, luminal AVP $\left(10^{-9} \mathrm{M}\right)$ stimulates $\mathrm{H}^{+}$-ATPase via the activation of V1 receptors [9]. In principal and intercalated cell of rabbit cortical collecting duct, AVP increases cAMP accumulation [10]; however, it has been suggested that in this duct, luminal AVP $\left(10^{-9} \mathrm{M}\right)$ impairs electrogenic $\mathrm{H}^{+}$secretion [11] and in rat medullary thick ascending limb cells, AVP does not affect $\mathrm{H}^{+}$-ATPase directly [12]. In addition, our data with MDCK cells suggest that the increase in $\left[\mathrm{Ca}^{2+}\right] \mathrm{i}$ and cAMP plays a role in regulating the dose-dependent stimulatory effect of AVP on $\mathrm{H}^{+}$-ATPase after $\mathrm{pHi}$ acidification, via $\mathrm{V} 1$ and $\mathrm{V} 2$ receptor mediated pathways; in agreement with these data, ANP or BAPTA inhibits the increase in $\left[\mathrm{Ca}^{2+}\right] \mathrm{i}$ in response to AVP and blocks the stimulatory effect of AVP on $\mathrm{H}^{+}$-ATPase [13].

Moreover, it is known that: 1) acute cellular acidification stimulates exocytosis and elicits a rapid increase in proton secretion that is mediated by an $\mathrm{H}^{+}$-ATPase [14]. 2) an increase in $\left[\mathrm{Ca}^{2+}\right]$ i might reflect a physiological mechanism to stimulate $\mathrm{H}^{+}$-ATPase-mediated protein export under acidic conditions $[15,16]$. 3) cAMP stimulates V-ATPase accumulation, microvillar elongation, and proton extrusion in kidney collecting duct A-intercalated cells [17] and 4) vesicle trafficking and exocytosis play a role in the regulation of $\mathrm{H}^{+}$transport in MDCK cells $[18,19]$.

Based on these findings, in the present study we investigated the effect of ANG II $\left(10^{-12}\right.$ and $\left.10^{-7} \mathrm{M}\right)$ or AVP $\left(10^{-12}\right.$ and $\left.10^{-6} \mathrm{M}\right)$ alone or plus ANP $\left(10^{-6} \mathrm{M}\right)$ on the subcellular acidic vesicle trafficking in MDCK cells following intracellular acidification using $\mathrm{NH}_{4} \mathrm{Cl}$. The experiments were performed in a $\mathrm{Na}^{+}$-free solution containing Schering 28080 (specifically inhibits $\mathrm{H}^{+} / \mathrm{K}^{+}$-ATPase), experimental conditions under which $\mathrm{H}^{+}$-ATPase is the only mechanism for pHi recovery in the MDCK cells [13]. To determine if blocking the increase in $\left[\mathrm{Ca}^{2+}\right] \mathrm{i}$ affects the ANG II or AVP stimulatory effect on acidic vesicle trafficking, BAPTA $\left(5 \times 10^{-5} \mathrm{M}\right)$ was added to the cells. Additionally, we investigated the interaction of ANG II or AVP plus colchicine $\left(10^{-5} \mathrm{M}\right.$, 2-h preincubation; inhibits microtubule-dependent vesicular trafficking [20]) on the acidic vesicle movement. Our data indicate that there is a dose-dependent stimulatory effect of ANG II or AVP on $\mathrm{H}^{+}$-ATPase subcellular vesicle trafficking, which is impaired by ANP or BAPTA. The results suggest a role for the $\left[\mathrm{Ca}^{2+}\right] \mathrm{i}$ in the regulation of these hormonal effects; whether $\left[\mathrm{Ca}^{2+}\right] \mathrm{i}$ is a direct mechanism or is a side effect of other signaling pathways which will require additional studies. Colchicine also abo- lishes these hormonal effects, suggesting that micro-tubuledependent $\mathrm{H}^{+}$-ATPase vesicular trafficking is involved in the stimulatory effect of ANG II or AVP on the pHi recovery mediated by $\mathrm{H}^{+}$-ATPase and impaired by ANP.

\section{MATERIALS AND METHODS}

\subsection{Cell Culture}

We used serial cultures of wild-type MDCK cells (American Type Culture Collection, Rockville, MD) at passage $66-75$ and exhibiting $320 \mathrm{ohm} \cdot \mathrm{cm}^{2}$ resistance (measured using EVOM, WPI), which is compatible with the cell strain I [21]. The cultures were maintained in Dulbecco's modified Eagle's medium (DMEM, Gibco, Grand Island, NY) supplemented with $2 \mathrm{mM}$ glutamine, $10 \%$ fetal bovine serum, $100 \mathrm{IU} / \mathrm{ml}$ penicillin and 100 $\mu \mathrm{g} / \mathrm{ml}$ streptomycin, at $37^{\circ} \mathrm{C}$ and in humidified air $(5 \%$ $\mathrm{CO}_{2}, \mathrm{pH}$ 7.4) in a $\mathrm{CO}_{2}$ incubator (Lab-Line Instruments, Melrose Park, IL). The cells were harvested using trypsin ethyleneglycol-bis (b-aminoethyl ether)-N, N'-tetraacetic acid (EGTA, 0.02\%), seeded on sterile glass coverslips and incubated for $72 \mathrm{~h}$ in the DMEM medium until confluent. At the time of the experiment, the mean $\mathrm{pHi}$ was $7.16 \pm 0.04(\mathrm{n}=97)$, measured by the exposure of the cells to $10 \mu \mathrm{M}$ BCECF-AM in the external solution, which was $\mathrm{HCO}_{3}^{-}$-free and at $\mathrm{pH} 7.4$ [22]; therefore, these MDCK cells are subtype C11 [23].

\subsection{Acidic Cytoplasmic Vesicle Movement}

The cells were loaded with acridine orange $5 \mu \mathrm{M}$ in control solution (mM: $\mathrm{NaCl} 145, \mathrm{KCl} 5, \mathrm{MgCl}_{2} 1, \mathrm{CaCl}_{2} 1.8$, HEPES 30, $\mathrm{Na}_{2} \mathrm{SO}_{4} 1, \mathrm{NaH}_{2} \mathrm{PO}_{4} 1$, Glucose $10 ; \mathrm{pH}=7.4$ ) for $30 \mathrm{~s}$ [24], and the subcellular acidic cytoplasmic vesicles were visualized at room temperature $\left(22^{\circ} \mathrm{C}\right)$ using a Zeiss LSM 510 confocal microscope (objective $63 \times$ ) [25]. The preparation was illuminated using an argon laser at $488 \mathrm{~nm}$, and the emission of fluorescence was measured between 515 and $565 \mathrm{~nm}$. A preliminary bleaching control was performed in the cells preincubated with the acridine orange in an $\mathrm{Na}^{+}$-free solution $(\mathrm{mM}: \mathrm{KCl} 5$, $\mathrm{MgCl}_{2} 1, \mathrm{CaCl}_{2}$ 1.8, HEPES 30, Glucose 10, N-methylD-glucamine 145; $\mathrm{pH}=7.4$ ) containing Schering 28080 $\left(10^{-5} \mathrm{M}\right)$, demonstrating that the fluorescent marker was taken up rapidly by the MDCK cells, concentrated in the cytoplasmic vesicles and not lost during the initial 12 min of the experiment. After acidification of the $\mathrm{pHi}$ by exposure to $\mathrm{NH}_{4} \mathrm{Cl}$ solution $(\mathrm{mM}: \mathrm{NaCl} 125, \mathrm{KCl} 5$, $\mathrm{MgCl}_{2} 1, \mathrm{CaCl}_{2} 1.8$, HEPES 30, $\mathrm{Na}_{2} \mathrm{SO}_{4} 1, \mathrm{NaH}_{2} \mathrm{PO}_{4} 1$, Glucose 10, $\mathrm{NH}_{4} \mathrm{Cl} 20 ; \mathrm{pH}=8$ ) for $2 \mathrm{~min}$, the rapid acidification of the cells and vesicles was observed, as a result of the $\mathrm{NH}_{3}$ efflux [8]. The acidification was accompanied by quenching of the acridine orange fluorescence. That is, acridine orange (AO) is a weak base that can permeate the vesicle membrane; when the vesicle becomes acidic, AO will enter the vesicle and form 
$\mathrm{AOH}^{+}$in the interior, where it accumulates. Therefore, as the vesicle becomes more acidic, the $\mathrm{AOH}^{+}$level becomes higher, decreasing the fluorescence; however, agents that stimulate the proton pumps make the vesicle less acidic and thus more fluorescent [24,26].

In the present work the $\mathrm{H}^{+}$-ATPase activity was assessed as the rate of increase in fluorescence occurring during the $\mathrm{pHi}$ recovery period after acid loading, in a $\mathrm{Na}^{+}$-free solution containing Schering 28080. In the control conditions, it was noted that during the $\mathrm{pHi}$ recovery period, the largest concentration of vesicles is around the nucleus and/or at the basolateral side of the cells. How-
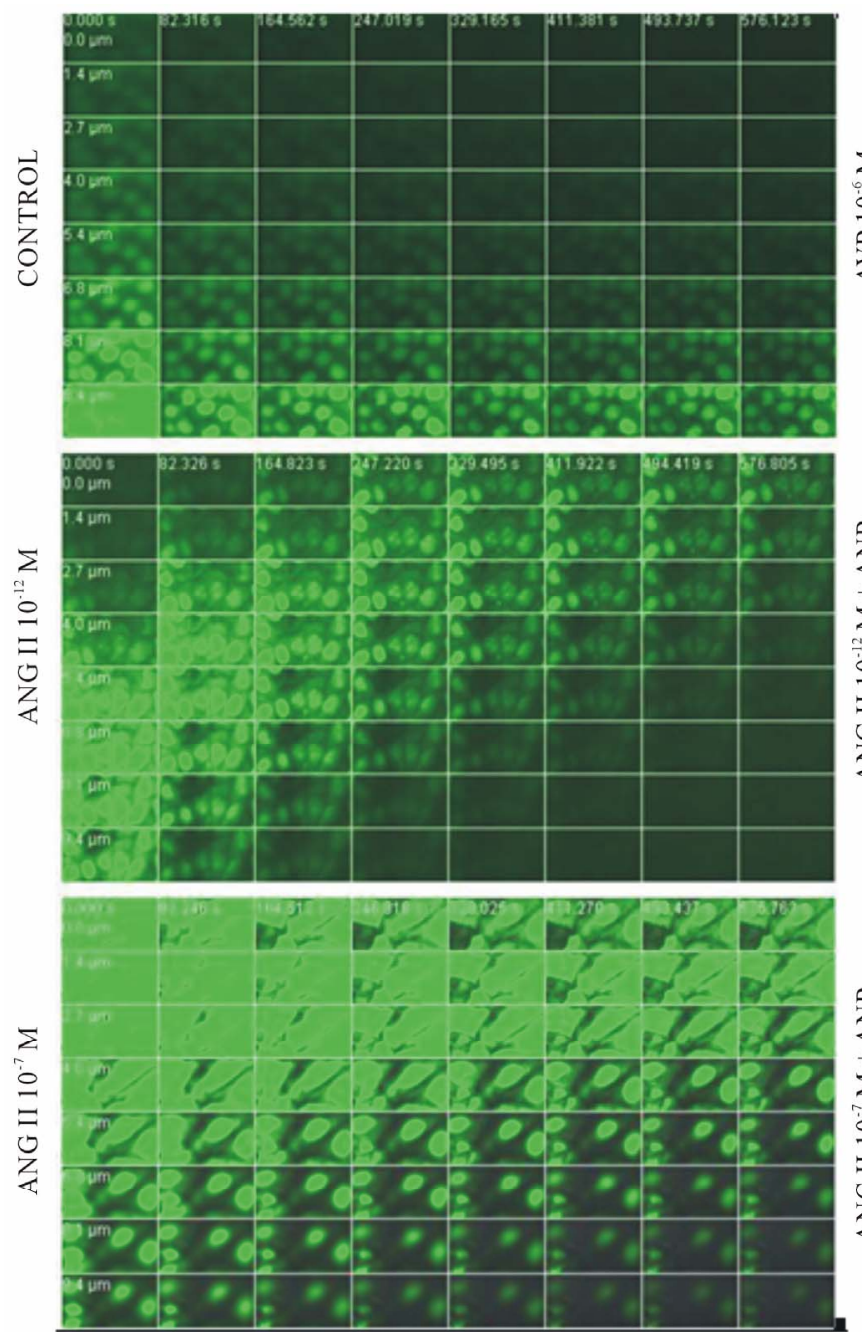

(a) ever, in presence of ANG II or AVP, as pHi recovery proceeds, the density of vesicles at the apical pole of the cells increases, suggesting their transfer toward this pole (Figures 1(a) and 2(a)).

To detect the movement of the cytoplasmic vesicles inside the cells during the pHi recovery period, the acridine orange fluorescence was measured [27] for a total of $10 \mathrm{~min}$ and a $\mathrm{z}$ sequence, at stepwise depths of $1.4 \mu \mathrm{m}$, was recorded every $82 \mathrm{~s}$. The $\mathrm{z}$ sequence started at the apical cell surface $(0 \mu \mathrm{m})$ and ended at the basolateral surface $(9.8 \mu \mathrm{m})$. The Figures 1 and $\mathbf{2}$ demonstrate the sequence of fluorescence images taken over time and
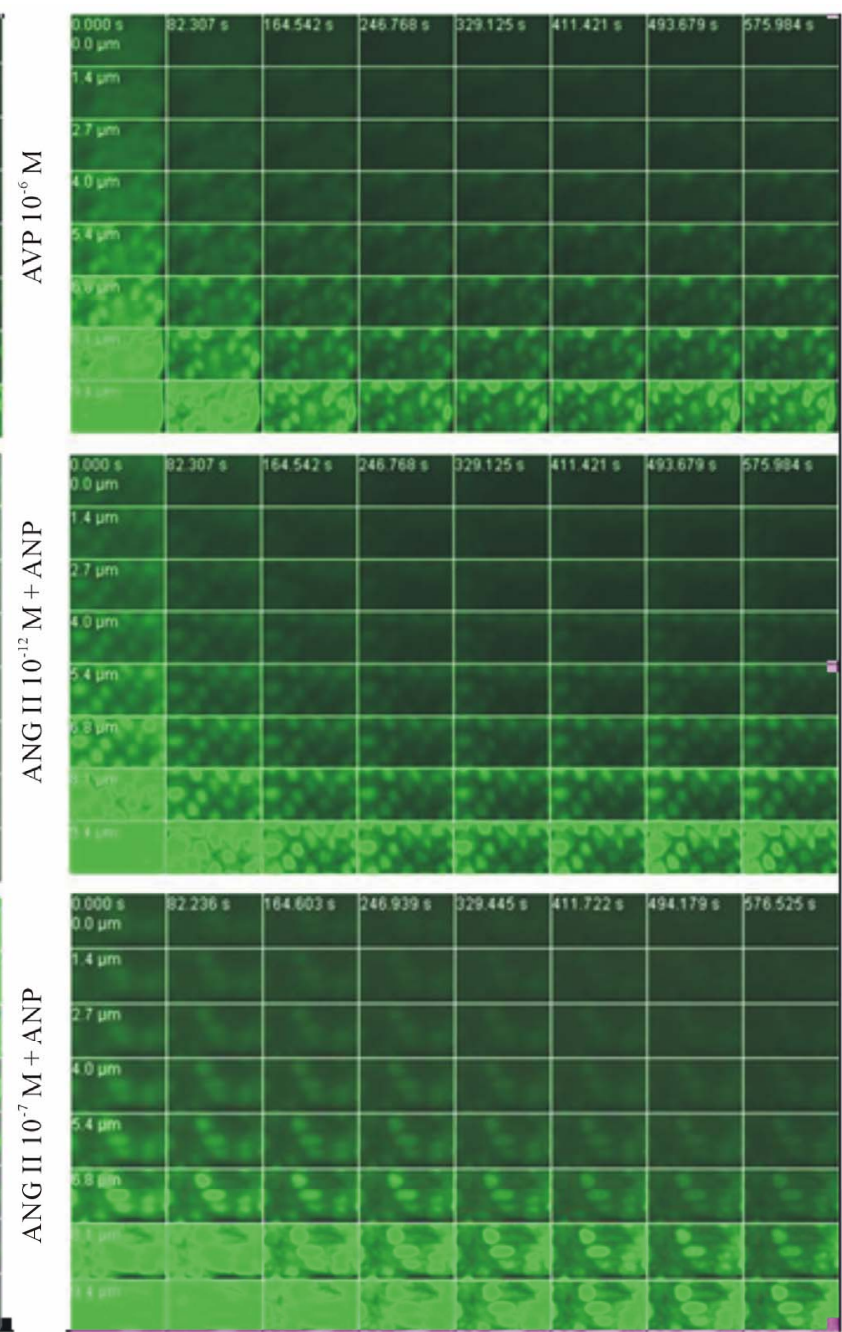

(b)

Figure 1. Confocal microscopy images of MDCK cells preincubated with acridine orange. Effect of ANG II $\left(10^{-12}\right.$ and $\left.10^{-7} \mathrm{M}\right)$ or/and ANP $\left(10^{-6} \mathrm{M}\right)$ on the movement of acidic vesicles within the cells during the pHi recovery period via $\mathrm{H}^{+}$-ATPase after the acid loading induced by $\mathrm{NH}_{4} \mathrm{Cl}$. The vesicular trafficking was followed by measuring the fluorescence density from the basolateral (lower) to the apical (upper) areas. Under the control conditions, during the entire period of pHi recovery the largest concentration of fluorescence was observed at the basolateral side of the cells. In presence of ANG II alone (a), as the pHi recovery progressed, the fluorescence density at the apical pole of the cells increased in a dose-dependent manner, suggesting the transfer of the acidic vesicles toward this pole. With ANP alone or plus ANG II (b), as the pHi recovery proceeded, the largest concentration of fluorescence was observed at the basolateral side of the cells, suggesting that the movement of the vesicles toward the apical pole did not occur. Objective $63 \times$, pinhole 347 , fluorescence density (in green). 


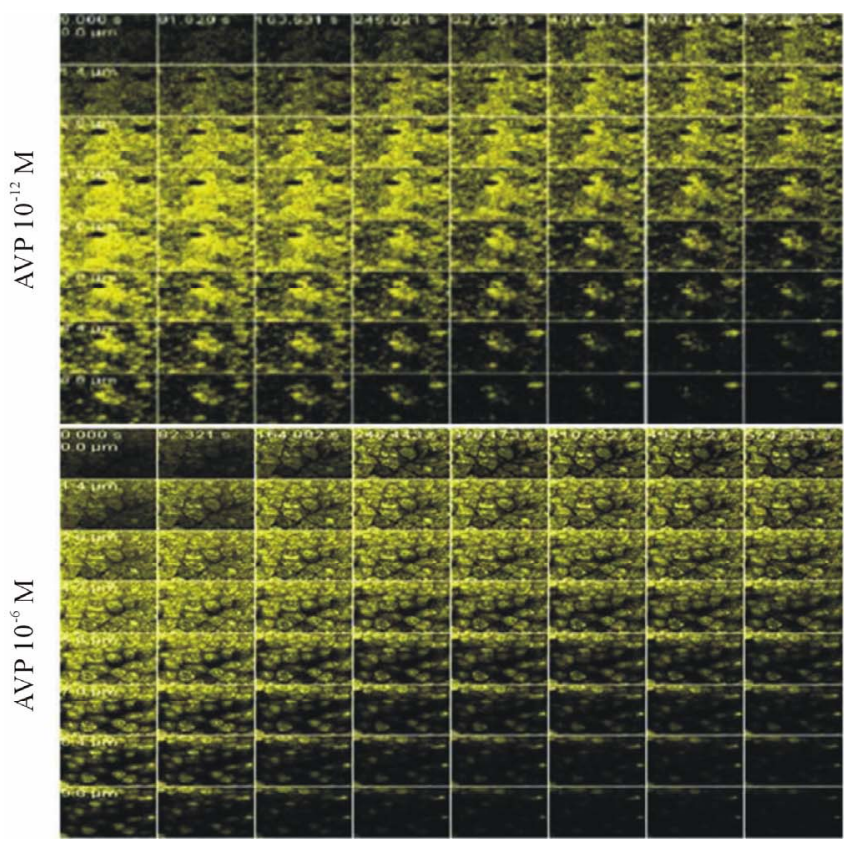

(a)

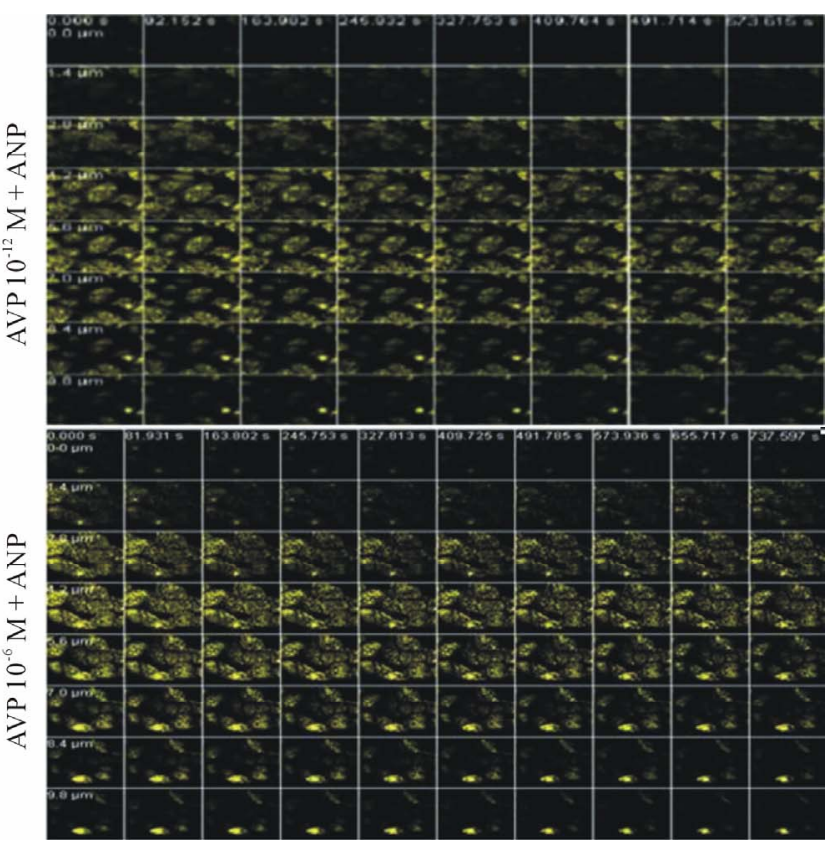

(b)

Figure 2. Confocal microscopy images of MDCK cells preincubated with acridine orange. Effect of AVP $\left(10^{-12}\right.$ and $\left.10^{-6} \mathrm{M}\right)$ or/and ANP $\left(10^{-6} \mathrm{M}\right)$ on the movement of acidic vesicles within the cells during the pHi recovery period via $\mathrm{H}^{+}$-ATPase after the acid loading induced by $\mathrm{NH}_{4} \mathrm{Cl}$. The vesicular trafficking was followed by measuring the fluorescence density from the basolateral (lower) to the apical (upper) areas. In the presence of AVP alone (a), as the pHi recovery progressed, the fluorescence density at the apical pole of the cells increased in a dose-dependent manner, suggesting the transfer of the acidic vesicles toward this pole. With AVP plus ANP (b), as the pHi recovery proceeded, the largest concentration of fluorescence was not observed at the apical side of the cells, indicating that the movement of the vesicles toward this pole did not occur. Objective $63 \times$, pinhole 347 , fluorescence density (in yellow).

indicate the z-axis depth. The images were stored on a $\mathrm{CD}$ and were analyzed using the Adobe Photoshop 6.0 image program. The movement of the vesicles was determined in 10 cells by measuring the fluorescence density of the cytoplasm from the basolateral to the apical areas (outside the cell nucleus). This process was quantified by determining the time course of the apical to basolateral cytoplasmic fluorescence density ratio [25]. The experiments were performed under control conditions or in the presence of ANG II $\left(10^{-12}\right.$ and $\left.10^{-7} \mathrm{M}\right)$ or AVP $\left(10^{-12}\right.$ and $\left.10^{-6} \mathrm{M}\right)$ and/or ANP $\left(10^{-6} \mathrm{M}\right)$, BAPTA $(5 \times$ $\left.10^{-5} \mathrm{M}\right)$ or colchicine $\left(10^{-5} \mathrm{M}\right.$, 2-h preincubation).

\subsection{Solutions and Reagents}

The osmolality of the solutions was approximately 300 $\mathrm{mOsmol} / \mathrm{Kg} \mathrm{H}_{2} \mathrm{O}$, which is the osmolality of the culture medium. ANP (28-aminacid) was purchased from Bachem Fine Chemicals (New Haven, CT, USA) and BAPTA was from Molecular Probes (Eugene, OR, USA). The ANG II (1046 molecular weight), AVP (molecular weight 1.084) and all other chemicals were obtained from the Sigma Chemical Company (St. Louis, MO, USA).

\subsection{Statistics}

The results are presented as the means \pm SEM; (n) is the number of experiments. The data were analyzed statistically by analysis of variance followed by Bonferroni's contrast test. Differences were considered significant if $\mathrm{p}$ $<0.05$.

The Biomedical Sciences Institute, University of São Paulo, Ethical Committee for Animal Research (CEEA) approved this study.

\section{RESULTS}

Figure 3 shows the fluorescent cytoplasmic vesicles in an MDCK cell preincubated under the preliminary experimental conditions, i.e., in the $\mathrm{Na}^{+}$-free solution containing Schering 28080 and in the absence of acid loading. The data indicate that acridine orange is taken up rapidly by the cell, concentrates in cytoplasmic vesicles and is not lost during the initial $12 \mathrm{~min}$ of the experiment (upper) and that ANG II $\left(10^{-12} \mathrm{M}\right)$ increases the number of vesicles that can be detected in the cytoplasm (lower).

Figures 1 and $\mathbf{2}$ demonstrate the movement of the fluorescent vesicles inside the cells during the pHi recovery period following the $\mathrm{NH}_{4} \mathrm{Cl}$ loading. As the pHi recovery proceeded, under the control conditions the largest concentration of fluorescence was observed at the basolateral side of the cells over time, and with ANG II $\left(10^{-12}\right.$ and $\left.10^{-7} \mathrm{M}\right)$ the fluorescence density at the apical pole of the cells exhibited a dose-dependent increase 


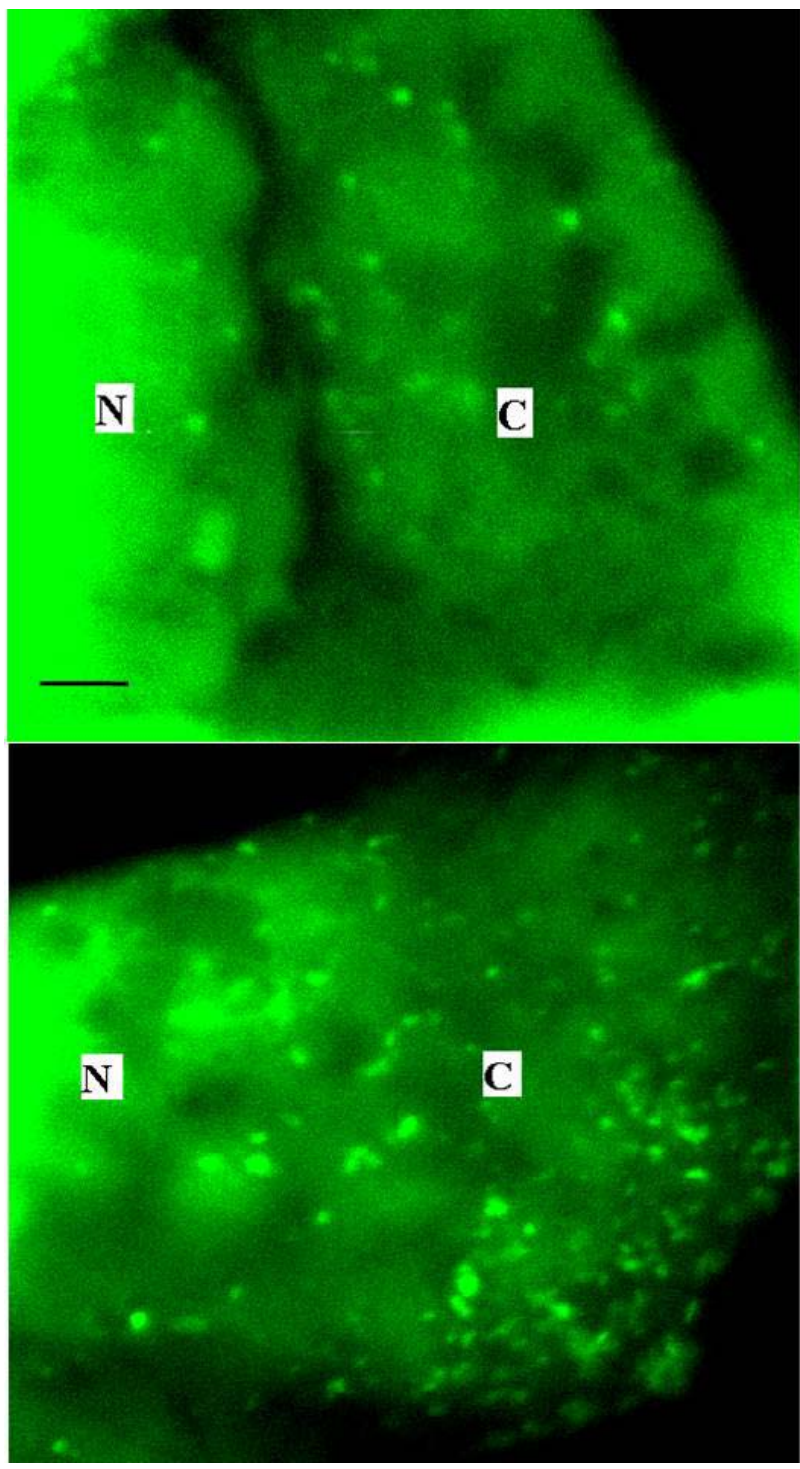

Figure 3. Fluorescent cytoplasmic vesicles in an MDCK cell preincubated with acridine orange in a $\mathrm{Na}^{+}$-free solution containing Schering 28080 in the absence of acid loading, under the control conditions (upper). The presence of ANG II $\left(10^{-12}\right.$ M) caused an increase in the number of vesicles that can be detected in the cytosol (lower). $\mathrm{N}=$ nuclei. $\mathrm{C}=$ cytoplasm. Bar $\cong 0.5 \mu \mathrm{m}$.

with time (Figure 1(a)). However, an increase in the fluorescence density at the apical pole was not observed with ANP alone or in combination with ANG II $\left(10^{-12}\right.$ and $10^{-7} \mathrm{M}$ ) (Figure 1(b)). As the pHi recovery proceeded in the presence of AVP $\left(10^{-12}\right.$ and $\left.10^{-6} \mathrm{M}\right)$ the fluorescence density at the apical pole of the cells exhibited a dose-dependent increase with time (Figure 2(a)); nevertheless, it did not increase in the presence of AVP $\left(10^{-12}\right.$ and $\left.10^{-6} \mathrm{M}\right)$ plus ANP (Figure 2(b)).

In addition, the results also indicate that, similar to what occurs with ANP, in the presence of BAPTA or colchicine alone or plus ANG II or AVP, as the pHi re- covery proceeded, the largest concentration of fluorescence was observed at the basolateral side of the cells, suggesting that the movement of the vesicles toward the apical pole was inhibited (Figures not shown).

Figure 4 ((a) upper and (b) upper) shows that, as the pHi recovery proceeded, under the control conditions the apical/basolateral fluorescence density ratio (FDap/ FDbl) remained almost constant over time. Already with ANG II $\left(10^{-12}\right.$ and $\left.10^{-7} \mathrm{M}\right)$ the FDap/FDbl increased markedly, particularly at $10^{-7} \mathrm{M}$ ANG II (Figure 4(a) upper); however, in the presence of ANG II $\left(10^{-7} \mathrm{M}\right)$ in combination with ANP, BAPTA or colchicine the (FDap/FDbl) demonstrated only minor changes over time (Figure 4(a) lower). In the presence of AVP $\left(10^{-12}\right.$ and $\left.10^{-6} \mathrm{M}\right)$, the FDap/FDbl exhibited a dose-dependent increase with time (Figure 4(b) upper); nevertheless, with AVP $\left(10^{-6}\right.$ M) plus ANP, BAPTA or colchicine the FDap/FDbl did not change significantly with time (Figure 4(b) lower). The mean slopes (changes in FDap/FDbl over time) of the lines shown in Figure 4 were calculated during the first $5.30 \mathrm{~min}$ of the pHi recovery period. Table 1 indicates that under the control conditions the mean slope was $0.079 \pm 0.0033 \mathrm{~min}^{-1}(\mathrm{n}=14)$, and that it increased significantly in the presence of ANG II, in a dose-dependent manner. However, this increase was not observed with ANP, BAPTA or colchicine alone or in combination with ANG II. Table 1 also demonstrates that in the presence of AVP the mean slopes increased markedly, in a dose-dependent manner. Yet, similar to ANG II, this increase was not observed with AVP plus ANP, BAPTA or colchicine.

\section{DISCUSSION}

The aim of this study was to clarify the influence of ANG II or AVP alone or in combination with ANP or other agents, on $\mathrm{H}^{+}$-ATPase subcellular vesicle trafficking after intracellular acidification by $\mathrm{NH}_{4} \mathrm{Cl}$, in MDCK cells strain I and subtype C11. Because two-thirds of these cells exhibited a peanut lectin binding capacity [23], they resemble intercalated cells in the renal collecting duct and are presumably the cells in which the $\mathrm{H}^{+}$-ATPase under investigation is localized. Supporting this proposal, the two $\mathrm{Na}^{+}$-independent proton secretion mechanisms found in these cells, the $\mathrm{H}^{+} / \mathrm{K}^{+}$-ATPase and the vacuolar $\mathrm{H}^{+}$-ATPase $[28,29]$, are similar to the mechanisms found in the intercalated cells of the mammalian collecting duct. The experiments were performed in an $\mathrm{Na}^{+}$-free solution (to inhibit the $\mathrm{Na}^{+} / \mathrm{H}^{+}$exchanger) and in the presence of Schering 28080 (to inhibit the $\mathrm{H}^{+} / \mathrm{K}^{+}$-ATPase), experimental conditions under which $\mathrm{H}^{+}-$ ATPase provides the only mechanism for pHi recovery in these cells [13], which is inhibited by concanamycin (a specific inhibitor of the vacuolar $\mathrm{H}^{+}$-ATPase) [29]. 

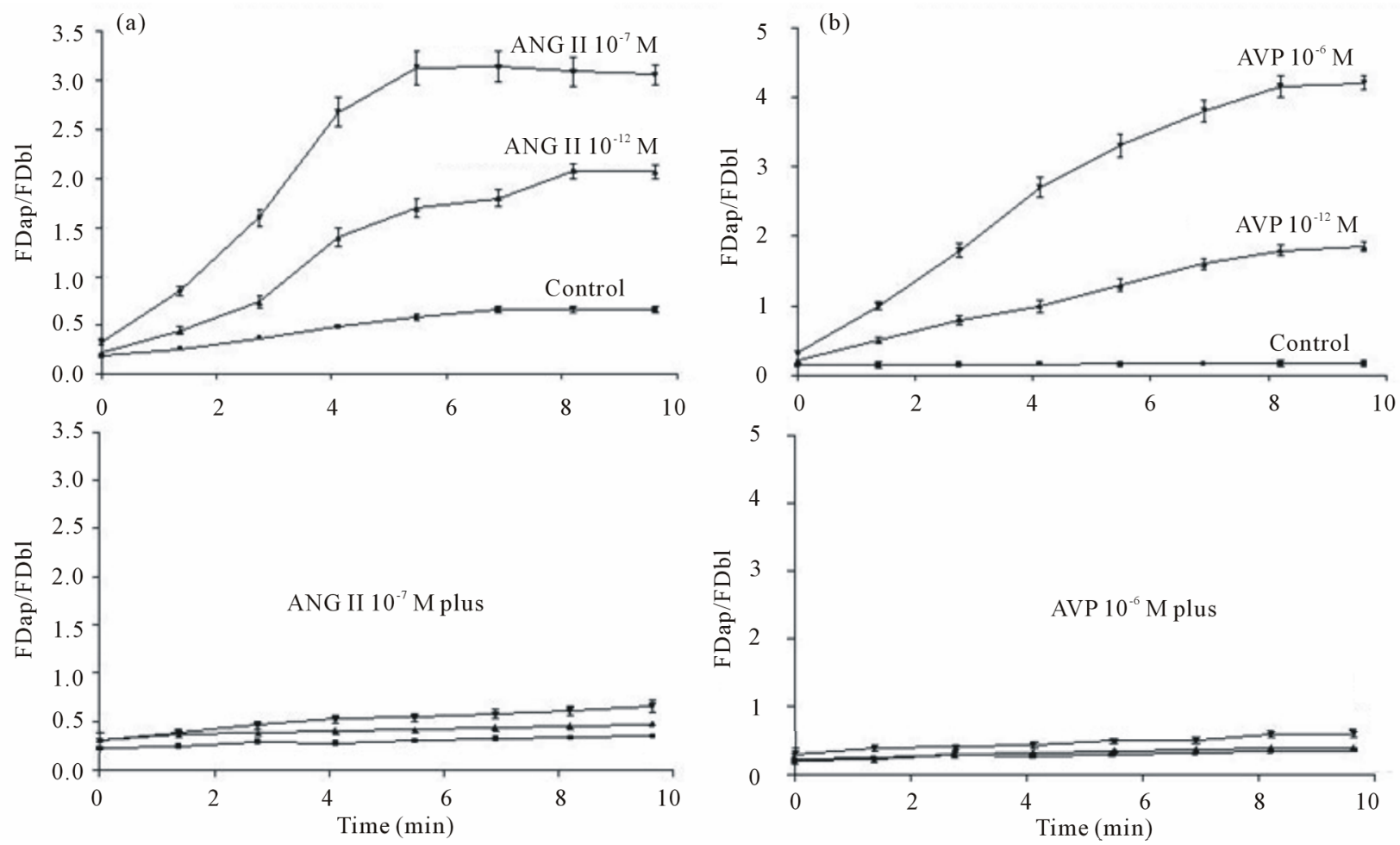

Figure 4. Mean time course of the apical $(0 \mu \mathrm{m})$ to basolateral $(9.4 \mu \mathrm{m})$ fluorescence density ratio (FDap/FDbl) in MDCK cells loaded with acridine orange during the $\mathrm{pHi}$ recovery via $\mathrm{H}^{+}$-ATPase after the acid loading. Under the control conditions, the FDbap/FDbl did not change significantly over time. However, in the presence of ANG II $\left(10^{-12}\right.$ and $\left.10^{-7} \mathrm{M}\right)((\mathrm{a})$ upper $)$ or AVP $\left(10^{-12}\right.$ and $\left.10^{-6} \mathrm{M}\right)\left((\mathrm{b})\right.$ upper), the FDap/FDbl increased markedly in a dose-dependent manner. But, with ANG II $\left(10^{-7} \mathrm{M}\right)$ or AVP $\left(10^{-6} \mathrm{M}\right)$ ((a) lower or (b) lower, respectively) plus ANP, BAPTA or colchicine, the FDap/FDbl exhibited only minor changes over time, indicating that the movement of the vesicles was inhibited. $\mathrm{N}=10$ cells.

Table 1. Effect of ANG II or AVP alone or plus ANP, BAPTA or colchicine on changes of apical/basolateral fluorescence density ratio over time, on MDCK cells loaded with acridine orange. The values were calculated during the first $5.30 \mathrm{~min}$ of $\mathrm{pHi}$ recovery after the $\mathrm{pHi}$ acidification by $\mathrm{NH}_{4} \mathrm{Cl}$ in a $\mathrm{Na}^{+}$-free solution containing Schering 28080.

\begin{tabular}{|c|c|c|c|}
\hline Experimental groups & $\min ^{-1}$ & Experimental groups & $\min ^{-1}$ \\
\hline Control & $0.079 \pm 0.0033(14)$ & & \\
\hline ANG II $\left(10^{-12} \mathrm{M}\right)$ & $0.322 \pm 0.038^{*}(13)$ & $\operatorname{AVP}\left(10^{-12} \mathrm{M}\right)$ & $0.301 \pm 0.018^{*}(12)$ \\
\hline ANG II $\left(10^{-7} \mathrm{M}\right)$ & $0.578 \pm 0.061^{*}(12)$ & AVP II $\left(10^{-6} \mathrm{M}\right)$ & $0.687 \pm 0.049^{*}(11)$ \\
\hline $\operatorname{ANP}\left(10^{-6} \mathrm{M}\right)$ & $0.058 \pm 0.015(10)$ & & \\
\hline ANP + ANG II $\left(10^{-12} \mathrm{M}\right)$ & $0.050 \pm 0.0094^{+}(11)$ & $\operatorname{ANP}+\operatorname{AVP}\left(10^{-12} \mathrm{M}\right)$ & $0.050 \pm 0.0098^{\S}(12)$ \\
\hline ANP + ANG II $\left(10^{-7} \mathrm{M}\right)$ & $0.048 \pm 0.0085^{\&}(13)$ & $\mathrm{ANP}+\operatorname{AVP}\left(10^{-6} \mathrm{M}\right)$ & $0.049 \pm 0.0081^{@}(11)$ \\
\hline $\operatorname{BAPTA}\left(5 \times 10^{-5} \mathrm{M}\right)$ & $0.015 \pm 0.013(12)$ & & \\
\hline BAPTA + ANG II $\left(10^{-12} \mathrm{M}\right)$ & $0.015 \pm 0.0006^{+}(12)$ & $\mathrm{BAPTA}+\operatorname{AVP}\left(10^{-12} \mathrm{M}\right)$ & $0.014 \pm 0.0083^{\$}(12)$ \\
\hline BAPTA + ANG II $\left(10^{-7} \mathrm{M}\right)$ & $0.051 \pm 0.0040^{\# \&}(12)$ & $\mathrm{BAPTA}+\mathrm{AVP}\left(10^{-6} \mathrm{M}\right)$ & $0.050 \pm 0.0038^{\# @}(11)$ \\
\hline Colchicine $\left(10^{-5} \mathrm{M}\right)$ & $0.051 \pm 0.018(10)$ & & \\
\hline Colchicine + ANG II $\left(10^{-12} \mathrm{M}\right)$ & $0.049 \pm 0.0011^{+}(11)$ & Colchicine + AVP $\left(10^{-12} \mathrm{M}\right)$ & $0.050 \pm 0.0015^{\S}(12)$ \\
\hline Colchicine + ANG II $\left(10^{-7} \mathrm{M}\right)$ & $0.048 \pm 0.0088^{\&}(13)$ & Colchicine $+\operatorname{AVP}\left(10^{-6} \mathrm{M}\right)$ & $0.049 \pm 0.0091^{@}(12)$ \\
\hline
\end{tabular}

Values are means \pm SE (number of experiments). ANG II = angiotensin II; AVP = arginine vasopressin; ANP = atrial natriuretic peptide; BAPTA = dimethyl-BAPTA/AM (an intracellular calcium chelator); Colchicine = an inhibitor of microtubule-dependent vesicular trafficking and Schering $28080=$ a specific inhibitor of $\mathrm{H}^{+} / \mathrm{K}^{+}$-ATPase. ${ }^{*} \mathrm{p}<0.01$ vs. Control; ${ }^{\sharp} \mathrm{p}<0.05$ vs. BAPTA alone; ${ }^{+} \mathrm{p}<0.01$ vs. ANG II $\left(10^{-12} \mathrm{M}\right)$ alone; ${ }^{*} \mathrm{p}<0.01$ vs. ANG II $\left(10^{-7} \mathrm{M}\right)$ alone; ${ }_{\mathrm{p}}<0.01$ vs. AVP $\left(10^{-12} \mathrm{M}\right)$ alone and ${ }^{\circledR} \mathrm{p}<0.01$ vs. AVP $\left(10^{-6} \mathrm{M}\right)$ alone. 
Under the preliminary experimental conditions in the absence of acid loading, our data indicate that the acridine orange was taken up rapidly by the cell, concentrated in the cytoplasmic vesicles and is not lost during the initial $12 \mathrm{~min}$. Thus, these data indicate that the time that the acridine orange remains inside the cell is greater than the time required to detect the movement of the acidic cytoplasmic vesicles inside the cells during the pHi recovery period following the $\mathrm{NH}_{4} \mathrm{Cl}$ loading (10 $\min )$.

\subsection{ANG II}

The present results show that, under the preliminary experimental conditions in the absence of acid loading, ANG II $\left(10^{-12} \mathrm{M}\right)$ increases the number of vesicles that can be detected in the cytosol, since ANG II stimulates the proton pumps making the vesicles less acidic and thus more fluorescent $[24,26]$. During the pHi recovery period following $\mathrm{pHi}$ acidification, our results demonstrate a dose-dependent stimulatory effect of ANG II $\left(10^{-12}\right.$ or $\left.10^{-7} \mathrm{M}\right)$ on $\mathrm{H}^{+}$-ATPase subcellular vesicle trafficking. These results are compatible with: 1) studies in MDCK cells showing that ANG II $\left(10^{-12}\right.$ and $\left.10^{-7} \mathrm{M}\right)$ stimulated the $\mathrm{pHi}$ recovery rate via $\mathrm{H}^{+}$-ATPase and the $\left[\mathrm{Ca}^{2+}\right] \mathrm{i}$ increase, in a dose-dependent manner [8]; 2) results in isolated rat proximal tubule fragments [1] and cells in culture [30], indicating that ANG II $\left(10^{-9} \mathrm{M}\right)$ stimulates proton extrusion via $\mathrm{H}^{+}$-ATPase by a process involving the membrane insertion of vesicles; 3) data from the cortical collecting duct of mice showing that the addition of ANG II to type A intercalated cells increases the ratio of apical plasma membrane $\mathrm{H}^{+}$-ATPase to cytoplasmic $\mathrm{H}^{+}$-ATPase three-fold [31] and 4) more recent results in kidney intercalated cells suggesting that the subcellular localization of V-ATPase and its activity is coupled with the acid-base status via PKA and AMPactivated protein kinase [32].

\subsection{AVP}

The present data demonstrate that as the $\mathrm{pHi}$ recovery proceeds following the $\mathrm{NH}_{4} \mathrm{Cl}$ pulse, $\mathrm{AVP}\left(10^{-12}\right.$ and $10^{-6}$ $\mathrm{M}$ ), similar to ANG II, has a dose-dependent stimulatory effect on $\mathrm{H}^{+}$-ATPase subcellular vesicle trafficking. Our data are in accordance with: 1) our previous experiments in MDCK cells indicating that AVP $\left(10^{-12}\right.$ and $\left.10^{-6} \mathrm{M}\right)$ has a dose-dependent stimulatory effect on the $\mathrm{pHi}$ recovery rate via $\mathrm{H}^{+}$-ATPase with the activation of $\mathrm{V} 1$ and $\mathrm{V} 2$ receptors and the synergy of the $\mathrm{Ca}^{2+} / \mathrm{PKC}$ and cAMP/PKA pathways [13], 2) studies in principal and intercalated cell of rabbit cortical collecting system demonstrating that AVP increases cAMP accumulation [10] and induces a $\left[\mathrm{Ca}^{2+}\right] \mathrm{i}$ increase mediated by $\mathrm{V} 2$ through a cAMP/PKA pathway [33] and 3) more recent data in collecting duct A-intercalated cells demonstrating that cAMP has profound effects on the distribution and function of the V-ATPase and on the stimulation of long membrane extensions and microvilli [17].

\subsection{ANP plus ANG II or AVP}

The current results indicate that ANP alone, or in combination with ANG II or AVP, does not affect the movement of the $\mathrm{H}^{+}$-ATPase subcellular vesicles. This behavior is in agreement with the studies showing that in the presence of ANP alone or plus ANG II [8] or AVP [13]: 1) the $\mathrm{pHi}$ recovery rate via $\mathrm{H}^{+}$-ATPase did not differ significantly from the control condition and 2) the effect of ANP on $\left[\mathrm{Ca}^{2+}\right]$ i. According these previous studies, ANP alone did not affect the speed of the pHi recovery because it caused a decrease in $\left[\mathrm{Ca}^{2+}\right] \mathrm{i}$ of approximately $40 \%$ of the control value, which by itself does not impair cellular $\mathrm{H}^{+}$secretion; however, ANP impaired the effect of ANG II or AVP on the speed of the pHi recovery because it impairs the increase in $\left[\mathrm{Ca}^{2+}\right] \mathrm{i}$ in response to ANG II or AVP, thus modulating the activity of these hormones in the cell. In addition, our data are in accordance with studies suggesting that an increase in $\left[\mathrm{Ca}^{2+}\right] \mathrm{i}$ might stimulate $\mathrm{H}^{+}$-ATPase-mediated protein export under acidic conditions $[15,16]$ and with studies showing that ANP inhibits the cAMP synthesis stimulated by AVP [34].

\subsection{BAPTA plus ANG II or AVP}

Similar to ANP, the shift in the fluorescence toward the apical pole of the cells does not occur with BAPTA alone or in combination with ANG II or AVP. Again, these data are consistent with previous findings concerning the action of BAPTA on the pHi recovery via $\mathrm{H}^{+}$-ATPase and on the $\left[\mathrm{Ca}^{2+}\right] \mathrm{i}$ in presence of ANG II $[5,8]$ or AVP [13]. That is, BAPTA alone does not modify the pHi recovery once it decreases the $\left[\mathrm{Ca}^{2+}\right]$ i to approximately $49 \%$ of the control value, which by itself does not affect $\mathrm{H}^{+}$secretion $[8,13]$. Similar to ANP, BAPTA impairs the effect of ANG II or AVP on $\mathrm{H}^{+}$-ATPase subcellular vesicle trafficking and on the pHi recovery because it impairs the stimulatory effects of these hormones on the increase in $\left[\mathrm{Ca}^{2+}\right]$ i. However, our current results show that in the presence of BAPTA plus ANG II $\left(10^{-7} \mathrm{M}\right)$, the change in FDap/FDbl over time exhibits a relatively small but significant difference compared to BAPTA alone $(\mathrm{p}<0.05$, Table 1). It is likely that this difference results from the significant increase in $\left[\mathrm{Ca}^{2+}\right]$ i observed in the presence of BAPTA plus ANG II $\left(10^{-7} \mathrm{M}\right)(24 \%$ above the control value [8]) which might initiate the movement of the vesicles toward the apical pole. Our present data also indicate that a similar scenario occurs in the presence of BAPTA plus AVP $\left(10^{-6} \mathrm{M}\right)$ (Table 1), although in this 
situation the increase in the $\left[\mathrm{Ca}^{2+}\right] \mathrm{i}$ observed was not significant (11\% above the control value [13]).

\subsection{Colchicine plus ANG II or AVP}

Colchicine disrupts microtubular structures and has been implicated in the vesicular trafficking of $\mathrm{H}^{+}$-ATPase along the nephron, especially in the translocation of intracellular vesicles [20]. Our data indicate that the fluorescence density at the apical pole did not increase in the presence of colchicine alone or plus ANG II or AVP. This behavior is consistent with data showing that in rat proximal tubular cells [1] and in intercalated cells from isolated mouse connecting tubules and cortical collecting ducts [3] the stimulation of $\mathrm{H}^{+}$-ATPase by ANG II required an intact microtubular network since it was completely inhibited by colchicine. Therefore, our colchicine data strongly suggest that in MDCK cells, ANG II or AVP stimulate the microtubule-dependent vesicular trafficking of acidic vesicles during the $\mathrm{Na}^{+}$and $\mathrm{K}^{+}$-independent $\mathrm{pHi}$ recovery period after the acid loading.

\section{CONCLUSION}

The present study in MDCK cells loaded with acridine orange indicates that, as the $\mathrm{pHi}$ recovery via $\mathrm{H}^{+}$-ATPase proceeded following the acid loading induced by an $\mathrm{NH}_{4} \mathrm{Cl}$ pulse, a dose-dependent ANG II $\left(10^{-12}\right.$ and $10^{-7}$ $\mathrm{M})$ or AVP $\left(10^{-12}\right.$ and $\left.10^{-6} \mathrm{M}\right)$ increase in fluorescence density at the cellular apical pole occurred, suggesting the transfer of acidic vesicles toward this pole and their possible incorporation into the apical membrane. This finding is consistent with our previous studies, also in MDCK cells, demonstrating a role for $\left[\mathrm{Ca}^{2+}\right] \mathrm{i}$ in regulating the process of $\mathrm{pHi}$ recovery mediated by $\mathrm{H}^{+}$-ATPase and stimulated by ANG II $\left(10^{-12}\right.$ and $\left.10^{-7} \mathrm{M}\right)$ [8] or AVP $\left(10^{-12}\right.$ and $\left.10^{-6} \mathrm{M}\right)[13]$ in a dose-dependent manner. Our present data, indicating that ANP or BAPTA does not affect the $\mathrm{H}^{+}$-ATPase subcellular vesicle trafficking, are in agreement with the results of our previous studies showing that ANP- and BAPTA-mediated decrease in $\left[\mathrm{Ca}^{2+}\right] \mathrm{i}$ to approximately $40 \%$ and $49 \%$ of the control values, respectively, do not affect the pHi recovery $[8,13]$. Furthermore, our current findings indicating that ANP or BAPTA impairs the effect of ANG II or AVP on $\mathrm{H}^{+}$-ATPase subcellular vesicle trafficking also agree with our earlier findings showing that ANP or BAPTA inhibits the increase in the $\left[\mathrm{Ca}^{2+}\right] \mathrm{i}$ in response to ANG II or AVP, which blocks the stimulatory effect of these hormones on the pHi recovery $[8,13]$, respectively. Therefore, the present study indicates that the increase in $\left[\mathrm{Ca}^{2+}\right]$, although not exclusive, plays a role in regulating the dose-dependent stimulatory effect of ANG II or AVP on $\mathrm{H}^{+}$-ATPase subcellular vesicle trafficking. Whether $\left[\mathrm{Ca}^{2+}\right]$ i reduction represents an important direct mechanism for ANP impairs this dose-dependent stimulatory effect of
ANG II or AVP, or is a side effect of other signaling pathways which will require additional studies. In addition, the current observation that the fluorescence density at the apical pole did not increase in the presence of colchicine plus ANG II or AVP strongly suggests that in MDCK cells, the microtubule-dependent vesicular trafficking of acidic vesicles is involved in the dose-dependent stimulatory effect of ANG II or AVP on $\mathrm{H}^{+}$-ATPase subcellular vesicle trafficking impaired by ANP.

\section{ACKNOWLEDGEMENTS}

This work was supported by Fundação de Amparo a Pesquisa do Estado de São Paulo (FAPESP) and Conselho Nacional de Pesquisas (CNPq). The authors thank Dr. Antonio Carlos Cassola for the assistance with the confocal microscope.

\section{REFERENCES}

[1] Wagner, C.A., Giebisch, G., Lang, F. and Geibel, J.P. (1998) Angiotensin II stimulates vesicular $\mathrm{H}^{+}$-ATPase in rat proximal tubular cells. Proceeding of the National Academy of Sciences of the United States of America, 95, 9665-9668.

[2] Barreto-Chaves, M.L.M. and Mello-Aires, M. (1996) Effect of luminal angiotensin II and ANP on early and late cortical distal tubule $\mathrm{HCO}_{3}^{-}$reabsorption. American Journal of Physiology: Renal Physiology, 271, F977-F984.

[3] Wagner, C.A., Mohebbi, N., Uhlig, U., Giebisch, G.H., Breton, S., Brown, D. and Geibel, J.P. (2011) Angiotensin II stimulates $\mathrm{H}^{+}$-ATPase activity in intercalated cells from isolated mouse connecting tubules and cortical collecting ducts. Cellular Physiology and Biochemistry, 28, 513-520. doi:10.1159/000335112

[4] Pech, V., Zheng, W., Pham, T.D., Verlander, J.W. and Wall, S.M. (2008) Angiotensin II activates $\mathrm{H}^{+}$-ATPase in type A intercalated cells. Journal of the American Society of Nephrology, 19, 84-91. doi:10.1681/ASN.2007030277

[5] Rothenberger, F., Velic, A., Stehberger, P.A., Kovacikova, J. and Wagner, C.A. (2007) Angiotensin II stimulates vacuolar $\mathrm{H}^{+}$-ATPase activity in renal acidsecretory intercalated cells from the outer medullary collecting duct. Journal of the American Society of Nephrology, 18, 20852093. doi:10.1681/ASN.2006070753

[6] Tojo, A., Tisher, C.C. and Madsen, K.M. (1994) Angiotensin II regulates $\mathrm{H}^{+}$-ATPase activity in rat cortical collecting duct. American Journal of Physiology: Renal Physiology, 267, F1045-F1051.

[7] Wall, S.M., Fischer, M.P., Glapion, D.M. and De La Calzada, M. (2003) ANG II reduces net acid secretion in rat outer medullary collecting duct. American Journal of Physiology: Renal Physiology, 285, F930-F937.

[8] Oliveira-Souza, M., Malnic, G. and Mello-Aires, M. (2002) Atrial natriuretic peptide impairs the stimulatory effect of angiotensin II on $\mathrm{H}^{+}$-ATPase. Kidney International, 62, 1693-1699. doi:10.1046/j.1523-1755.2002.00604.x

[9] Barreto-Chaves, M.L.M. and Mello-Aires, M. (1997) Lu- 
minal arginine vasopressin stimulates $\mathrm{Na}^{+}-\mathrm{H}^{+}$exchange and $\mathrm{H}^{+}$-ATPase in cortical distal tubule via $\mathrm{V} 1$ receptor. Kidney International, 52, 1035-1041.

doi:10.1038/ki.1997.425

[10] Fejes-Toth, G. and Naray-Fejes-Toth, A. (1989) Isolated principal and intercalated cells: Hormone responsiveness and $\mathrm{Na}^{+}-\mathrm{K}^{+}$-ATPase activity. American Journal of Physiology: Renal Physiology, 256, F742-F750.

[11] Ando, Y., Tabei, K. and Asano, Y. (1991) Luminal vasopressin modulates transport in the rabbit cortical collecting duct. Journal of Clinical Investigation, 88, 952-959. doi:10.1172/JCI115398

[12] Borensztein, P., Juvin, P., Vernimmen, C., Poggioli, J., Paillard, M. and Bichara, M. (1993) cAMP-dependent control of $\mathrm{Na}^{+} / \mathrm{H}^{+}$antiport by AVP, PTH, and $\mathrm{PGE}_{2}$ in rat medullary thick ascending limb cells. American Journal of Physiology: Renal Physiology, 264, F354-F364.

[13] Oliveira-Souza, M., Musa-Aziz, R., Malnic, G. and MelloAires, M. (2004) Arginine vasopressin stimulates $\mathrm{H}^{+}$ATPase in MDCK cells via V1 (cell $\mathrm{Ca}^{2+}$ ) and V2 (cAMP) receptors. American Journal of Physiology: Renal Physiology, 286, F402-F408. doi:10.1152/ajprenal.00121.2003

[14] Schwartz, J.H., Masino, S.A., Nichols, R.D. and Alexander, E.A. (1994) Intracellular modulation of acid secretion in rat inner medullary collecting duct cells. American Journal of Physiology: Renal Physiology, 266, F94-F101.

[15] Hou, Y., Wu, Q. and Delamere, N.A. (2001) H $\mathrm{H}^{+}$-ATPasemediated cytoplasmic $\mathrm{pH}$-responses associated with elevation of cytoplasmic calcium in cultured rabbit nonpigmented ciliary epithelium. Journal of Membrane Biology, 182, 81-90.

[16] Wagner, C.A., Finberg, K.E., Breton, S., Marshansky, V., Brown, D. and Geibel J.P. (2004) Renal vacuolar $\mathrm{H}^{+}$ATPase. Physiological Reviews, 84, 1263-1314. doi:10.1152/physrev.00045.2003

[17] Păunescu, T.G., Ljubojevic, M., Russo, L.M., Winter, C., McLaughlin, M.M., Wagner, C.A., Breton, S. and Brown, D. (2010) cAMP stimulates apical V-ATPase accumulation, microvillar elongation, and proton extrusion in kidney collecting duct A-intercalated cells. American Journal of Physiology: Renal Physiology, 298, F643-F654. doi:10.1152/ajprenal.00584.2009

[18] Brewer, C.B. and Roth, M.G. (1995) Polarized exocytosis in MDCK cells is regulated by phosphorylation. Journal of Cell Science, 108, 789-796.

[19] Mostov, K.E., Verges, M. and Altschuler, Y. (2000) Membrane traffic in polarized epithelial cells. Current Opinion in Cell Biology, 12, 483-490. doi:10.1016/S0955-0674(00)00120-4

[20] Brown, D., Sabolic, I. and Gluck, S. (1991) Colchicineinduced redistribution of proton pumps in kidney epithetlial cells. Kidney International, 40, S79-S83.

[21] Richardson, J., Scalera, V. and Simmons, N.L. (1981) Identification of two strains of MDCK cells which resemble separate nephron tubule segments. Biochimica et Biophysica Acta, 673, 26-36. doi:10.1016/0304-4165(81)90307-X

[22] Oliveira-Souza, M. and Mello-Aires, M. (2000) Inter- action of angiotensin II and atrial natriuretic peptide on pHi regulation in MDCK cells. American Journal of Physiology: Renal Physiology, 279, F944-F953.

[23] Gekle, M., Wuensch, S., Oberleithner, H. and Silbernagl, S. (1994) Characterization of two MDCK cell subtypes as a model system to study principal cell and intercalated cell properties. Pflügers Archiv, 428, 157-162. doi:10.1007/BF00374853

[24] Clerc, S. and Barenholz, Y. (1998) A quantitative model for using acridine orange as a transmembrane $\mathrm{pH}$ gradient probe. Analytical Biochemistry, 259, 104-111.

[25] Malnic, G. and Geibel, J.P. (2000) Cell pH and $\mathrm{H}^{+}$secretion by $\mathrm{S} 3$ segment of mammalian kidney: Role of $\mathrm{H}^{+}$-ATPase and $\mathrm{Cl}^{-}$. Journal of Membrane Biology, 178, 115-125. doi:10.1007/s002320010019

[26] Yang, L., Leong, P.K., Chen, J.O., Patel, N., Hamm-Alvarez, S.F. and McDonough, A.A. (2002) Acute hypertension provokes internalization of proximal tubule NHE3 without inhibition of transport activity. American Journal of Physiology: Renal Physiology, 282, F730-F740.

[27] Bevensee, M.W.B. (2008) Control of Intracellular pH, In: Seldin, D.W. and Giebisch, G., Eds., The Kidney, Physiology and Pathophysiology, Elsevier, New York, 1429. 1480 .

[28] Fernandez, R. and Malnic, G. (1998) $\mathrm{H}^{+}$-ATPase and $\mathrm{Cl}^{-}$ interaction in regulation of MDCK cell $\mathrm{pH}$. Journal of Membrane Biology, 163, 137-145. doi:10.1007/s002329900378

[29] Fernandez, R., Oliveira-Souza, M. and Malnic, G. (2000) $\mathrm{Na}^{+}$-independent proton secretion in MDCK-C11 cells. Pflügers Archiv, 441, 287-293. doi:10.1007/s004240000411

[30] Carraro-Lacroix, L.R. and Malnic, G. (2006) Signaling pathways involved with the stimulatory effect of Angiotensin II on vacuolar $\mathrm{H}^{+}$-ATPase in proximal tubule cells. Pflügers Archiv, 452, 728-736.

doi:10.1007/s00424-006-0085-2

[31] Pech, V., Zheng, W., Pham, T.D., Verlander, J.W. and Wall, S.M. (2008) Angiotensin II activates $\mathrm{H}^{+}$-ATPase in type A intercalated cells. Journal of the American Society of Nephrology, 19, 84-91. doi:10.1681/ASN.2007030277

[32] Gong, F., Alzamora, R., Smolak, C., Li, H., Naveed, S., Neumann, D., Hallows, K.R. and Pastor-Soler, N.M. (2010) Vacuolar $\mathrm{H}^{+}$-ATPase apical accumulation in kidney intercalated cells is regulated by PKA and AMP-activated protein kinase. American Journal of Physiology: Renal Physiology, 298, F1162-F1169.

doi:10.1152/ajprenal.00645.2009

[33] Van Baal, J., Raber, G., De Slegte, J., Pieters, R., Bindels, R.J.M. and Willems, P.H.G.M. (1996) Vasopressin-stimulated $\mathrm{Ca}^{2+}$ reabsorption in rabbit cortical collecting system: Effects on cAMP and cytosolic $\mathrm{Ca}^{2+}$. Pflügers Archiv, 433, 109-115. doi:10.1007/s004240050255

[34] Ishikawa, S., Saito, T., Okada, K., Kuzuya, T., Kangawa, K. and Matsuo, H. (1985) Atrial natriuretic factor increases cyclic GMP and inhibits cyclic AMP in rat renal papillary collecting tubule cells in culture. Biochemical and Biophysical Research Communications, 130, 1147-1153. doi:10.1016/0006-291X(85)91735-8 